\title{
Digital Content Marketing - A Literature Review on Concepts, International Experiences and Implications for Vietnam
}

\author{
Nguyen Hong Quy ${ }^{l^{*}}$ and Feifei Sun ${ }^{2 *}$ \\ ${ }^{1}$ FPT University, 391A Nam Ky Khoi Nghia, Ward 7, District 3, HCMC, Vietnam \\ ${ }^{2}$ School of Social Science, University of Queensland, St Lucia, Brisbane QLD 4072, Australia
}

\begin{abstract}
Communication activities are increasingly more diverse, complex and play a more important role in brand building. Perceived consistency of brand messages (across campaigns), a new variable that reflects an important aspect of the integration performance of marketing communications, has been included in the investigation of the impact of marketing communications. It has been shown that perceived consistency strongly correlates with brand's perception, attitude and behavior changes of the target audience. However, the mechanism of influence of this factor in the communication process is still a question for further research.
\end{abstract}

This paper aims to synthesize from pervious literature the international experiences in digital content marketing and draw the implications for enterprises when considering Vietnam settings. One major finding is that content marketing is about "helping" customers approach, and it is very customer-oriented: customers dictate what message works on what social channels. There are some lessons as following: Firstly, enterprises should formulate a "customercentric" content marketing strategy based on customer insights and data. Moreover, companies can directly and indirectly affect the content on digital platforms. Direct methods involve adding content, participating in discussion mediating employees' behaviors on social network. Indirect methods include providing employees with training on social network behavior so as to produce positive brand image. In addition, if an enterprise deploys multi-channel content marketing, it should be aware that different digital platforms work best with different message appeals.

Keywords: Digital marketing; Content marketing, Content marketing strategy; Message appeals; Vietnam digital marketing

\section{Introduction}

Content marketing is nothing novel and has been around since the dawn of advertising (Lou et al, p. 1, 2019). By 2019, content marketing is expected to be a 300-billion-dollar industry and more companies are using content marketing (86 percent of B2C organizations and 91 percent of B2B). In addition, most of those who are using it are increasing their budgets each year. Overall, 26 percent of the total marketing budget is dedicated to content marketing for the B2B sector. The number for B2C is 22 percent. The most successful organizations spend closer to 40 percent of their total marketing budget on content strategy. However, For B2B marketers, on average, 70 percent of content created never gets used (Marketing Insider Group p.16, 47, 48, 2018). These numbers show that organizations are well aware of the impact content marketing can have.

In today's world where technology and digital have integrated into almost every part of our lives, people's extensive use of the Internet and online platforms gave rise to a whole new subgroup of content marketing: Digital content marketing. In Vietnam alone, $95 \%$ of population access Internet on a daily basis (Hootsuite, 2018) an adult spends on average 2.12 hours on online social network (VinaResearch, 2018). Online social network has been and will continue to be an important tool for working, for entertainment purposes and for news and information to Vietnamese people. Moreover, online shopping is quickly becoming more popular: It is estimated that by 2025 , online spenders will make up half of Vietnam's annual total consumption (Nielsen Research, 2017). Consumers are continually exposed to digital messaging, thus relevant and value-rich content is more likely to make lasting impression by standing out from other noise clutter (Lou et al, 2019).

*Corresponding author: ${ }^{1}$ quynh6@,fe.edu.vn 
"An understanding of how content can be used in marketing, or more specifically, in engaging customers, is central to the development of an effective inbound [relevant-to- customer] marketing approach" (Holliman, 2014). Moreover, content marketing costs 62 percent less than outbound yet generates three times as many leads (Marketing Insider Group p.46, 2018). It also drives conversion rates that are six times higher than other marketing methods. With that said, it is undoubtedly very important to develop effective online content marketing strategy. This paper reviews existing literature on content marketing to meet the following objectives: (1) understand the key concepts of content marketing and digital content marketing, (2) what has been done on digital content marketing in other countries and (3) how can Vietnamese organization take international experiences to help develop an effective online content marketing campaign.

\section{Research methodology}

A systematic literature review of academic research on social media marketing has been conducted to gather, examine and synthetize studies related to content marketing, especially content marketing conducted on digital platforms. By following a review protocol based on both automatic and manual search, all relevant studies on aforementioned topic were identified and analyzed. After reviewing, implications will then be drawn out and how international experiences can be applied into Vietnamese context.

\subsection{Integration of marketing communication: a continuing evolution faced with information technology changes}

Communication is often understood as means of exchange between different parties to seek a shared meaning, from which to nurture and build relationships. In marketing, communication is considered one of four major tools, alongside with product, price and place, that helps businesses competitively and efficiently reach and satisfy customers' needs (Kotler \& Keller, 2016). Pressure from the competition is constantly pushing businesses to innovate and apply new communication techniques to connect and maintain relationships with customers, building up and strengthening its position in the customer's mind. Thereby, marketing communication activities are constantly expanding and changing, and require marketers to have a systematic and long-term vision of brand building and brand communication. Integrated marketing communication is a familiar concept used starting from the $90 \mathrm{~s}$ of the last century and defined as a strategic process that involves planning, implementing and evaluating branded communication programs, to persuade current and potential customers, partners and other stakeholders in the long- term (Schultz \& Kitchen, 1997). As stated by Schultz (2004), the continuum of integration of communication tools from tactical solution to strategic orientation may be divided into four phases (Figure 1):

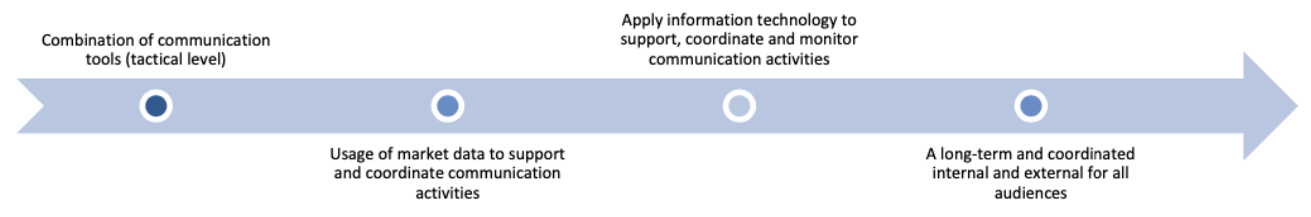

Fig. 1. Four phases of integrated marketing communication development (Schultz, 2004)

According to Schultz (2004), this process reflects the reality of perception and implementation of brand communications by executives in which integration is broadening and taking an increased strategic vision, ranging from low to high level.

With the recent development of information technology, especially the exponential growth of the Internet and smartphones, the way consumers communicate, search for information, buy and consume goods has changed considerably, notably with the younger generation. According to Batra and Keller (2016) "consumers today interact with a variety of media in a mix and non-traditional way". Information technology has created a new communications environment that is mobile, interactive, connected and highly personalized. Online and digital media do not actually kill traditional media, but they add to the list of new options for the consumers. Schultz (2011) proposed a brand communication inbound/outbound model - in addition to the principle of "pull - push". This includes a combination of both strategically and proactively delivered messages from the firm, with information and data which customers seek by themselves and firms do not officially "control". 


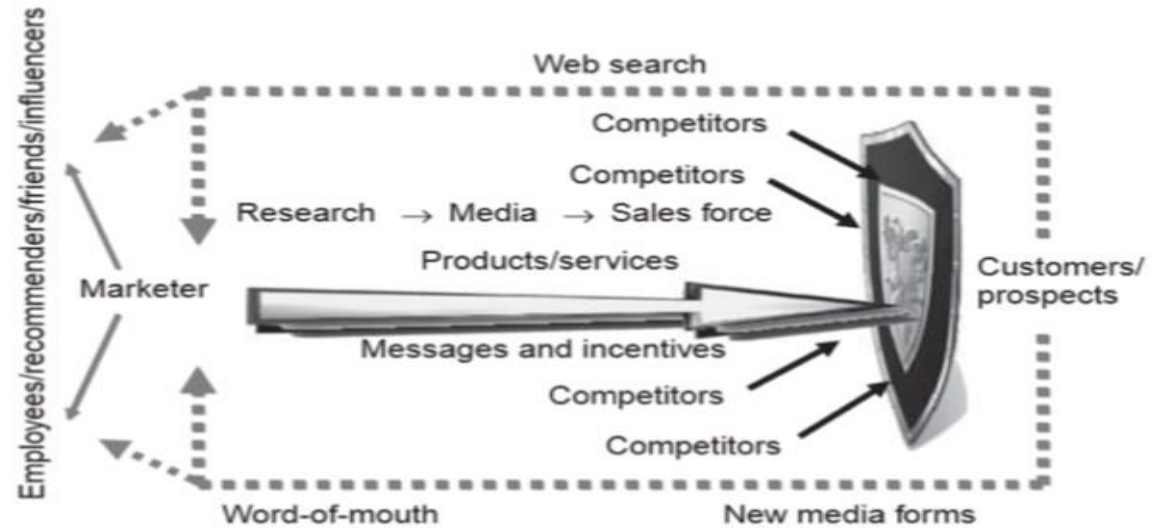

Fig. 2. Outbound and inbound brand marketing communication (Schultz, 2011)

\subsection{Measurement of integrated marketing communication's impact}

Marketing communication's impact is usually assessed on an individual-campaign basis. Various models have been proposed to synthesize the process through which branded messages influence the brand's choice of the target customer. Some of the most influential authors in this area may be listed as Lavidge \& Steiner (1961) with HierarchyOf-Effect model, which includes Awareness - Knowledge - Liking - Preference - Conviction - Purchase (Figures 3). This model is originated from AIDA (Attention-Interest-Desire- Action) - the classic acronym for capturing communication effect attributed to Lewis from 1898 (Hall, 2002).

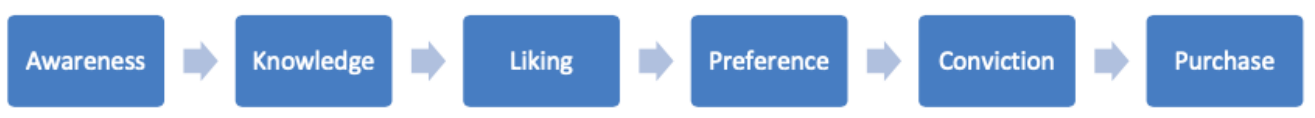

Fig. 3. Hierarchy-Of-Effect Model (Lavidge \& Steiner, 1961)

In a literature review of the impact of a marketing communication activity, Belch (2007) summarized and divided general impact measurement into three categories covering cognitive, emotional and behavioral changes of the target audience, after exposure - the preliminary condition for a communication activity to take place (the degree to which the message is likely to reach the public):

- Perception of the brand: the brand message being recognized and noticed. To assess customer's perceptual change as a result of exposure to some promotional messages, experimental techniques could be used to measure content recall and / or brand recognition, brand associations and brand trust.

- Affection or attitude toward the brand: positive emotions created for the message, the brand, and / or the company. To capture brand affection as a latent outcome of successful marketing communication activities, previous research usually use attitudinal Likert scale.

- Brand choice behavior: behavioral responses are important manifestations of the impact of brand communication. Some specific indicators to measure this variable include intention to try, repurchase tendency, brand loyalty, and actual brand conversion.

In Vietnam, some authors have investigated the topic of measuring communication effectiveness. Hoang Thi Bao Thoa (2013) in the article "Usage of modern advertising tools in Vietnam today" has analyzed the implementation of marketing communication activities. The author has evaluated advantages as well as limitations of traditional communication tools being used by Vietnamese enterprises. Nguyen Hoang Sinh (2013) studied the impact of point-ofpurchase (POP) techniques in retailing market and demonstrated the increasing role of promotion at the point-ofpurchase versus traditional mass-media marketing communications. In general, research conducted in Vietnam mostly offer a broad description and assessment of marketing communication as a whole promotional tool. Little is known on successive impact of marketing communication on different behavioral stages of the audience. Besides, a number of market research companies and media agencies, such as Nielsen, Taylor Nielson Sofres, to serve their clients, 
conducted ad-hoc surveys to evaluate the effectiveness of some specific campaigns. However, those studies applied to specific brands or programs, therefore were primarily of practical purpose.

To assess the synergistic impact of an entire campaign, which usually includes several communication activities when the need for consistency, complementarity and synergy between tools and media is in play, additional aspects of communication performance have emerged and attracted attention of the research community. Although the number of studies addressing integration performance is still limited, it is possible to identify three aspects that pioneering researchers are focusing on (Lee \& Park, 2007; Batra \& Keller, 2016). These includes:

- Consistency or commonality (of messages and content): The audience can recognize an idea and image throughout messages of communication campaigns over time. Messages in marketing communication should be understood in a larger sense, which do not necessarily limit in verbal communications. A public relation activity or a sale promotion activity, without any explicit verbal message, could both confer some meaning about the brand image.

- Complementarity (of communication tools): by their respective characteristics and functions, communication activities and tools interact effectively through coordination and resonance to impact different groups of audience.

- Strengthening brand relationship with target customers: Communication activities achieve the ultimate goal of enhancing and tightening the relationship between customers and the brand.

However, previous research addressing integrated communication performance remained largely at a conceptual level. The operationalization of concepts such as commonality or consistency of message, complementarity of communication tools, or strengthened brand relationship was still missing. Also, few studies investigate simultaneously the integration performance and the general (or traditional) communication impact, which are changes in customer's perception of the brand, attitude and behavior toward the brand, after being exposed to marketing communication messages. These two issues are often independently studied - possibly for the reason that due to their strategic nature and long-term vision - integration is primarily approached from the marketer's viewpoint, while the impact of communication is often studied from the perspective of customer's change. This research gap could represent a promising topic, since simultaneous consideration of the impact of marketing communication in general, and the synergistic effect in particular, will have important implications for managers to better coordinate communication tools and messages and to optimize marketing budget.

\section{Research findings}

\subsection{Concepts}

Several researchers and institute have put forward the definition of content marketing and in general, these do not differ much in terms of meaning. According to Joe Pulizzi- founder of content Marketing institute, content marketing is "a strategic marketing approach focused on creating and distributing valuable, relevant, and consistent content to attract and retain a clearly defined audience - and, ultimately, to drive profitable customers action" (Content Marketing Institute, 2018). Taking the same approach, (Holliman p.279, 2014) defined it as "Valuable, compelling and relevant content on a consistent basis to attract and retain customers through information that they actually want to receive". Or as cited in Jason Miller (2016) “It isn't advertising. It isn't push marketing, in which messages are sprayed out at groups of consumers. Rather, it's a pull strategy - it's the marketing of attraction. It's being there when consumers need you and seek you out with relevant, educational, helpful, compelling, engaging, and sometimes entertaining information" (Rebecca Lieb, Principal at Conglomotron LCC). Overall, it can be inferred from the definitions that content marketing is a strategy to lure a specific scope of customers by creating value-rich, relevant and consistent content that viewers can relate to. "Content marketing is about delivering the content your audience is seeking in all the places they are searching for it. It is the effective combination of created, curated and syndicated content." Michael Brenner, CEO, Marketing Insider Group.

Regarding the concept of digital content marketing, the difference doesn't lie in the end- goal but rather, the platform on which the content marketing plans are executed. According to Holliman and Rowley, digital content marketing is "the activity associated with creating, communicating, distributing, and exchanging digital content that has value for customers, clients, partners, and the firm and its brands" (Holliman, 2014, p. 287). And generally, existing body of literature on digital content marketing suggests that content marketing play a beneficial role in brand building (Ahmad et al., 2016; Harad, 2013; Hutchins and Rodriguez, 2018; Pulizzi, 2012, 2014; Koljonen, 2016; Schultz, 2016) all cited in (Lou, 2019)). By continually offering valuable content, brands can generate electronic word-of-mouth (eWOM), build trust and credibility, and achieve significant reach and impact (du Plessis, 2017; Muntinga et al., 2011 cited in (Lou et al, 2019)), as well as mould engaged and loyal customers (Walters, 2015) cited in (Lou et al, 2019)).

Scholars also pointed out the main difference between (digital) content marketing and advertising. "While content marketing may share the same defining goal as advertising, it differs in its approach (Neff, 2015). Advertising adopts persuasive tactics with the sole intention of selling products, whereas content marketing tends to educate (impart knowledge on specific topics), to expose (opinion sharing) and to entertain (provide enjoyment) (Harad, 2013). These two share the same ultimate goal which is to trigger more product sales; however, the former takes a more explicit approach while the latter aims to produce relevant, valuable content that meets customer needs (Holliman and Rowley, 2014; Schultz, 2016). 


\subsection{Role of content marketing}

The ultimate goal of marketing is to "create value for customers and build strong customers relationships to capture value from customers in return" (Philip Kotler, 2015). However, the statement is to a large extent a generalization, and marketing and especially content marketing should be examined further than that to fully understand what their roles are. In its publication, Marketing Insider Group (p.5, 2018) proposes the following business advantage of good content Marketing:

- Increase in website traffic. Marketing leaders see 7.8 times higher year-over-year growth in unique site traffic

- More leads. Content marketing garners 3 times as many leads as paid search for every dollar spent.

- Thought leadership. Brands who offer relevant, useful content are viewed as thought leaders in their industry, which helps to build brand trust and authority.

- Higher conversion rates. Organizations who use content marketing see 6 times higher conversion rates.

- Leaner budget. According to Demand Metric, it costs 62 percent less to launch and maintain a content marketing campaign than any other type of campaign.

- More attention on your brand. 20 percent of the time users are on the internet, they're consuming content.

All of these advantages will lead up to more products sold, revenue increased, and business grown (Marketing Insider Group p.6, 2018). This brings us back to Kotler's statement. However, blindly spending capitals to shove viewers with "buckets of content" is not the way to go. "In order to get a competitive advantage from content marketing, you need to have a strategy. It's about using a holistic approach, using different content channels to support one another and maintaining a meaningful brand story throughout" (Marketing Insider Group p.6, 2018). In the section 4.2 , we will discuss how to build an effective content marketing strategy.

\subsection{Content creation in social media by B2B companies}

As we mention above "for B2B marketers, on average, 70 percent of content created never gets used" (Marketing Insider Group p.48, 2018). If such were the case, then what are the best practices for B2B content marketing to minimize cost but also fully amplify the effect? In this section we examine two bodies of literature, "Analysis of content creation in social media by B2B companies" (Huotari, 2014) and "Business to business digital content marketing: marketers' perceptions of best practice" (Holliman, 2014) to have insights and a preferred, methodological practice to B2B content marketing.

With regards to the purpose of each study, both studies want to draw attention to the B2B content marketing phenomenon, which has not been approached by previous literature. "Social media tools are becoming an interesting component of B2B marketing because of the roles of personal relationships and interactions in these markets. However, research has not approached social media content creation from a B2B marketing perspective". While (Huotari, 2014) study aims to examine how business-to-business (B2B) marketers can influence content creation in social media in general, (Holliman, 2014) goes a step further and offers insights and reflections on what is considered good digital content marketing practices.

Both studies adopted the qualitative research methodology. More specifically, both studies invited experts in their respective business fields to have semi-structured interviews. As (Holliman p.276, 2014) has reasoned: "Such approach is useful for understanding and developing rich descriptions of interviewees' attitudes, perceptions and behaviours (Bryman and Bell, 2011; Saunders et al., 2009), and may act as a basis for theory-building. In addition, Daymon and Holloway (2011) suggest that qualitative research techniques are useful when gathering data from professionals such as marketing communications practitioners".

In Huotari (2014), users of B2B marketing are broken into 2 groups: Internal users (ones who are company payroll) and external users (including corporate users - ones using corporate account to represent the company, employee users, professional and civilian users). It is concluded in this research that "B2B firms engaging in social media as part of their marketing efforts should carefully consider the roles and activities of various users". Moreover, B2B company can either directly or indirectly influence content creation in social media. Direct method involves adding new content, participating in discussions and removing content through corporate user accounts and controlling employee social media behavior. Indirect method involves proactively provide employees training to create desired content and performing marketing activities that influence other users to create content that is favorable for the company. In terms of professional and civilian users, professional communities are valuable for B2B companies because their employees can promote their professionalism to other professionals. Thus, employees of B2B companies can create positive brand image promote their products and services to appropriate business audiences. However, not all civilian communities are appropriate and companies should control their choice of this channel.

In Holliman (2014), it is suggested to have an effective content marketing, fundamental changes are to be made in the mindset: instead of the outdated "selling" idea, content marketing requires a "helping" and "publishing" approach (which will require different marketing objectives, tactics, metrics and skills to those associated with more traditional marketing approaches). And to do so, it is critical to develop an insight of the audience's information needs, and their purchase consideration cycle. This put forward the idea of customer-centric and data-driven marketing as will be discussed further on into this paper. 


\subsection{Message appeals and orientation in social media brand communication}

It is hard to deny the importance of digital content marketing in today's settings. But exactly how brand communicate with customers and how effective are message appeals and orientation still needs further examination. To look into this problem, we review previous literature by (Kusumasondjaja, 2018): "The roles of message appeals and orientation on social media brand communication effectiveness". This research focuses on message appeals across social platforms, namely Facebook, Instagram and Twitter. These are also 3 of 5 social networks with highest brand recognition in Vietnam (VinaResearch, 2018); Therefore, the findings in the Indonesian research can have great carryover to Vietnam.

The purpose of this research is understanding how brands use Facebook, Twitter, and Instagram to interact with consumers and evaluating the effectiveness of different types of social media platforms. This study also aims to compare consumer responses to social media content orientation and message appeals among those platforms.

The appeal is the one factor that relates the brand and its consumers' desires and the connecting element that glues consumers to the advertising content (Dix and Marchegiani, 2013 cited in (Kusumasondjaja, 2018)). The research focus on three kinds of message appeals: rational (or informational), emotional (transformational) and mixed. Rational appeal usually demonstrates brand value, economy, popularity, convenience, health, performance, durability, or emphasizes the functional value of the brand (Dix and Marchegiani, 2013 cited in Kusumasondjaja, 2018). Meanwhile, emotional or transformational appeal presents the message about a brand to target audience by stressing the intangible and objectively unverifiable elements of the advertised brand (Liu and Stout, 1987 cited in Kusumasondjaja, 2018). Mixed appeal is a combination of emotional and informational appeals.

Communication orientation refers to the format or manner by which a message content is created that facilitates the interaction between firms and consumers (Williams and Spiro, 1985 cited in (Kusumasondjaja, 2018)). Communication orientation can be clustered into three dimensions: task orientation, interaction orientation, and self-orientation (Sheth, 1976 cited in (Kusumasondjaja, 2018)). Task orientation is defined as highly goal-oriented and purposeful communication with more focus on sales tasks to achieve organizational objectives (Miles et al., 1990 in (Kusumasondjaja, 2018)). Self-oriented communication is self-oriented communication style focuses on fulfilling communicator's personal needs and interests during interactions with others (Miles et al., 1990). Meanwhile, interaction orientation refers to a communication style stressing on forming friendships and fostering interpersonal relationships (Bass, 1960 cited in (Kusumasondjaja, 2018)).

The study employed a content analysis to obtain insights on the content of social media communication activities. Content analysis is considered as a standard method for systematically investigating the content of communications by quantifying and analyzing the words, concepts, and relationships within text (McAlister and Erffmeyer, 2003 cited in (Kusumasondjaja, 2018)). The researchers collected data from each individual social media post including Facebook, Instagram, and Twitter, generated by 43 brands in the list of the 2016 Brandz Top 50 Indonesian Brands. What recorded included the numbers of responses (likes/favorite/loves and comments), content orientation (task, self and interaction) and message appeal (information, emotional, and mixed information-emotional).

By analyzing the data, the researcher found that interactive brand posts were responded more frequently than informative message content. Twitter was more effective for informative appeal, Facebook worked better for interactive entertainment posts, and Instagram was more suitable for interactive content combining informative-entertainment appeals. Interactive brand post with mixed appeals received the most responses in Facebook and Instagram, while selforiented message with informative appeal obtained the least.

The author goes on to explain that this finding partially relates with the features on those social platforms. He advised marketers avoiding self-oriented posts and paying more attention to interactive message using mixed appeals when engaging social media users. He also suggested that Facebook and Instagram are more effective for long-term interaction building, while Twitter is a more appropriate channel for promoting awareness and spreading information.

A potential limitation is the fact that the social media accounts observed in this study were only major Indonesian brands. Another limitation in terms of Vietnam implication is that the study is done on Indonesian leading social network, not Vietnam's. Therefore, carryover should be taken with cautions.

\section{Discussion and implications of research}

\subsection{Vietnamese digital marketing landscape}

According to (Brands Vietnam, 2018), digital marketing has the fastest growth amongst Vietnamese marketing industry, up to $28 \%$ a year. By 2020, total market volume is expected to reach USD 340 million. Demographically, Vietnam population has surpassed 96 million, 64 million of which has access to the Internet. 85\% percent of those have social network accounts with online time falling within 25 hours weekly (Vo, 2018). This shows the untapped potentials of Vietnam digital marketing. Google user behavior reports show, before making shopping decisions, up to $70 \%$ of user's research product on the internet. Most of the search options are the information channel, social networks, brand websites and e-commerce sites (Dong, 2017). This statistic is backed by empirical findings by (Lou et al, 2019): "Consumers derive value from the relevant content and subsequently form more favorable brand attitudes, greater brand loyalty and heightened purchase intentions. 
Brand loyalty mediates the effect of perceived brand content value on purchase intentions". Thus, a customer-centric digital content marketing campaign is important. However, companies need a strategy, and without the right overall strategy to guide, efforts will end up in vain on digital tactics due to possible problems such as wrong audience orientation, brand value proposition not strong enough... ((Vo, 2018), (Marketing Insider Group p.48, 2018)).

Regarding Vietnam digital content marketing trends, there are 3 trends of content marketing (Vo, 2018): (1) Datadriven marketing, (2) video content and (3) utilization of mobile devices. (1) The use of data into digital marketing is not unfamiliar. In reality, before pushing content, data analysis must take place to ensure right audience orientation with the right message, at the right time. Thus, data collection and analysis are not independent from content marketing but rather, an integrated step to make sure who we target is right before "giving them high-quality content that is very relevant to them on a consistent basis" (Neil Patel in the Michael Brenner (2018), p8). (2) As data from Google provides, Vietnam ranks in the top 5 countries with most YouTube views, and according to (Vo, 2018)'s observations and figures by Google, over the last year, $65 \%$ of companies in Vietnam have increased their video advertising budgets, and video advertising costs on YouTube also increased, accounting for $16 \%$ of the average total advertising cost of brands. This shows that video is still a preferred method of content marketing. (3) To see the importance of mobile-led marketing, we provide some of the latest mobile data in Vietnam market as follows (Vo, 2018): with 64 million internet users, the number of simultaneous users accessing via mobile are $96 \%$ of internet users; accounting for $64 \%$ of Vietnam's population, of which $72 \%$ regularly use $3 \mathrm{G} / 4 \mathrm{G}$ to access the internet. Each mobile user accesses the internet on average 2.8 hours/day compared to 2.4 hours/day of desktop.

Aware of the importance and the trends of digital marketing, Vietnamese companies are spending an increasingly large amounts of money into it. In addition to businesses that are "burning money" into advertising, it is traders who are household business and individuals who sell online, which also contribute significantly to the growth of the industry (Dong, 2017). The fact that salons, dentists, food stores ... spend $25-30 \%$ of sales, or clothing, footwear stores ... spend up to $100 \%$ of profits on Facebook to receive orders showed that online advertising is the biggest "money-burning" channel of businesses. "The cost for advertising on our Facebook is about 1 billion / month", Ms. Pham Thi Hue, Chief Accountant A.O. Smith Vietnam revealed (Huu Tuan, 2019). However, digital marketing is not as expected for many. To explain for this, Le Dac Thinh Hong - Chairman of Websosanh (cited in (Dong, 2017)), attributed it to an instinctive marketing campaign rather than analysis-driven campaign. This once again highlights the need for a content marketing strategy.

\subsection{Experiences for Vietnam on building an effective content marketing strategy}

Michael Brenner - CEO of Marketing Insider Group proposed the following guideline to develop effective content marketing strategy. It uses the 3 P's of effective content marketing: Priority, Purpose, Personalization (Marketing Insider Group, 2018)

Priority: In order to have a good content marketing strategy, brands need to identify what's driving the strategy by identifying the reason behind chosen strategy; in other words, the goal. With effective content marketing, it's the priority goals that drive the strategy. Business needs to have a desired goal before building the strategy around it. The goal serves as the direction to base the plan onto. Without clear goal first, strategies may lead to unprioritized outcome that can hinder the business. Priorities should be the ones that are aligned with business goals. Be specific on which goals/issue one wants to address first. This is similar to having clear goals.

Personalization: Today's content marketers need to be thinking personalization when developing strategy. Personalized email offers, product suggestions and other personalized contents are what customers expect today. Write personalization into the content marketing strategy. This ensures that each customer feels related to the content of the marketing. In content marketing, relatability and relevancy are crucial to viewer's retention.

In Vietnamese marketing landscape, AI-integrated marketing and data-driven marketing are among top trends of 2019 (Vo, 2018). With the help of the right marketing automation platforms, marketers are using machine learning and predictive analytics to tailor content for both individuals and buyer segments, which creates a better experience.

Purpose: As have mentioned, content marketing is not brand-centric but focuses on customers. Therefore, rather than aligning the customer to the business, align the business to the customer. Your business purpose should align with what the customers seeks. To find the brand purpose, it is advisable to ask oneself simple, back-to-basics questions: What are the values of your brand? What purpose does your business have - how is it impacting society? How can your products and services make your customers' lives better?

\subsection{Experiences for Vietnam on content creation for B2B companies}

The key takeaway for B2B companies is that B2B digital content marketing is an inbound (customer-focused) marketing technique. It is not solely about selling products anymore like traditional methods of marketing. Content marketing is about "helping" customers approach, and it is very customer-oriented: customers dictate what message works on what social channels; and strategy should be based on customer insights and data. \#

Another finding is that company brand image can be directly as well as indirectly influenced. As research suggested, direct method involves adding new content, participating in discussions and removing content through corporate user accounts and controlling employee social media behavior. Indirect method involves proactively provide employees 
training to create desired content and performing marketing activities that influence other users to create content that is favorable for the company. This implies that content marketing should not just be the responsibility of a certain department, but as an integrated part of every employee. Their employees can promote their professionalism to other professionals, especially on professional channels. Employees of B2B companies can create positive brand image, consciously or accidentally, to promote their products and services to appropriate business audiences. This brings forward the needs to provide training for employees on social network behaviors. This is something Vietnamese companies can apply into their settings.

\subsection{Experiences for Vietnam on message appeals across different social platforms}

In (Kusumasondjaja, 2018) paper, empirical data showed that interactive contents had higher reach (were responded more frequently) than informative contents. Moreover, different social network platforms have its own most effective message methods. More specifically, Twitter users digest informative contents more effectively, posts that are interactive and entertaining work best on Facebook, and Instagram was more suitable for interactive content combining informative-entertainment appeals. In terms of mixed appeals, interactive contents with mixed appeals are best received on Facebook and Instagram, while self-oriented, brand-centric message with informative appeal obtained least traffic.

The implications for Vietnam settings are apparent. Firstly, content should not be brand- centric but customeroriented. The backbone of content marketing is that customer should be able to find it relevant. Viewers scroll through thousands of contents daily. If a content is not relatable nor entertaining, it will not be retained amongst other noise. In order to appeal to viewers, in-depth, data-driven analysis on customers should be conducted, not just based on guts feeling or industry hunch. As discussed previously in Vietnamese digital marketing landscape, digital marketing should be an integrated part of content marketing and if done right will generate valuable insights into customers' behavior.

Secondly, if a business deploys multiple platforms to perform digital content marketing on, they should vary their content according to the networks. There is no one-size-fits-all content across channels. To fully optimize the benefits of omni-platform presence, brand should put efforts into publishing posts with different message appeals. This way, brand can have most exposure in each platform. Another potential of content differentiation between platforms is that it introduces a sense of novelty and innovation into the brand image. When a viewer sees posts with different content of the same brand on different platforms, it can convey the message that the brand is always renewing themselves. This keeps customers anticipating for the next content and consequentially, retain them.

\section{Conclusion}

Social media tools are becoming an interesting component of content marketing because of the roles of personal relationships and interactions between customers and providers. It allows the conveyance of information between marketers and customers to become more rapid and abundant. Therefore, to increase attractiveness and the retention of information, raising the quality of content is essential. Content marketing should not be shoving content into customers but rather, shoving the right content: it should be based on what the customers want and appeal to so that they can relate to it.

Regarding implications for Vietnam companies, strategizing a content marketing campaign should be the first step. And in this step, insights and data on customers are to be based into not just "what feels right". Moreover, different social platforms need different message appeals. There is no lazy, one-size-fits-all content for all networks, and one company should invest efforts into generating different content across channels. In addition, content is can be influenced directly (through proactive campaign to promote a certain brand image) or indirectly (through what the personnel of the company - which in this case becomes a social representative, show on the digital platform). Therefore, content generation should not be just the business of one department but an integrated part of company, and employees should be trained to carry the desired brand image./.

\section{References}

Avlonitis, G. J., \& Gounaris, p. P. (1999). Marketing orientation and its determinants: an empirical analysis. European journal of marketing, 33(11/12), 1003- 1037.

Batra \& Keller, (2016.) Integrating Marketing Communications: New Findings, New Lessons, and New Ideas. Journal of Marketing, Volume Vol. 80, p. 122-145.

Belch, G. E., (2007). Evaluating the Effectiveness of Elements of Integrated Marketing Communications: A Review of Research. In: A Paradigm Shift from Traditional Media Planning. ICFAI University Press.

Content Marketing Institute (2018), "What is content marketing?", available at: http://contentmarketinginstitute. com/what-is-content-marketing/ (accessed 22 Oct. 2019).

Darroch, J. (2005). Knowledge management, innovation and firm performance. Journal of knowledge management, 9(3), 101-115.

Dong Phuong. (2017, August 27). Doanh nghiệp Việt “ngốn tiền” vào quảng cáo trục tuyến. Retrieved from VnExpress.net: https://vnexpress.net/kinh-doanh/doanh- nghiep-viet-ngon-tien-vao-quang-cao-truc-tuyen3633068.html (Accessed 26 Oct. 2019). 
Hall, (2002). A New Model for Measuring Advertising Effectiveness. Journal of Advertising Research, March-April.

Harad, K. (2013). Content marketing strategies to educate and entertain. Journal of Financial Planning Vol.26 No.3, $18-20$.

Holliman, G. R. (2014). Business to business digital content marketing: marketers' perceptions of best practice. Journal of Research in Interactive Marketing, 269-293.

Hoàng Thị Bảo Thoa, (2013). Usage of modern advertising tool in Vietnam today. Special Edition Economics and Business - Scientific Review, Hanoi National University, 29 (3).

Hootsuite, W. a. (2018, January 30). Digital in 2018: World's Internet users pass the 4 billion mark. Retrieved from wearsocial.com: https://wearesocial.com/blog/2018/01/global-digital-report-2018 (Accessed 24 Oct. 2019).

Huotari, L. U. (2014). Analysis of content creation in social media by B2B companies. Journal of Business \& Industrial Marketing, 761-770.

Huu Tuan (2019), Quảng cáo trực tuyến “đốt tiền” doanh nghiệp, theo đường link: https://baodautu.vn/quang-cao-tructuyen-dot-tien-doanh-nghiep-d90097.html, truy cập ngày 25/10/2019.

Kotler P. \& Keller, K. L., (2016). A Framework for Marketing Management. 6th Edition ed. United States : Pearson Education.

Kusumasondjaja Sony (2018), The roles of message appeals and orientation on social media brand communication effectiveness: An evidence from Indonesia. Asia Pacific Journal of Marketing and Logistics Vol.30 No.4, p.11351158.

Lavidge \& Steiner, (1961). A model for Predictive Measurements of Advertising Effectiveness. Journal of Marketing, 25(Oct), pp. 59-62.

Lee \& Park, (2007). Conceptualization and Measurement of Multidimensionality of Integrated Marketing Communications. Journal of Advertising Research, Issue September.

Lou, C. X. (2019). Does non-hard-sell content really work? Leveraging the value of branded content marketing in brand building. Journal of Product and Brand Management.

Neff, J. (2015, October 12). Is it Content or is it Advertising? Retrieved from AdAge: https://adage.com/article/ad-ageresearch/content-advertising/300858 (Accessed 21 Oct. 2019).

Nielsen Research Report (2017, July 09). Meet the connected spenders - potential consumer of the future (Ngươi tiêu dùng kết nối - khách hàng tiềm năng trong tương lai của các doanh nghiệp. Retrieved from nielsen.com: https://www.nielsen.com/vn/vi/insights/report/2017/connected-spenders-nielsen- 2017/\# (Accessed 24 Oct. 2019).

Nguyễn Hoàng Sinh, (2013). Assessment of Point-of-Purchase communication efforts in Vietnamese retailing market. Development and Integration Review, 10(20), 42-45.

Marketing insider group (2018), The Ultimate guide to content Marketing, available at: https://go.marketinginsidergroup.com/ultimate-marketing-content- guide?utm_source=slim-banner, (accessed 1 Aug 2019).

Philip Kotler, G. A. (2015). Principles of Marketing 16th edition. Pearson Education Press.

Quáng cáo trục tuyến: cuộc chiến giũa doanh nghiệp nội và ngoại (Digital marketing: the war between international and domestic agencies). (2018, May 09). Retrieved from Brands Vietnam: https://www.brandsvietnam.com/congdong/topic/339-Quang-cao-truc-tuyen- cuoc-chien-giua-doanh-nghiep-noiva-ngoai (Accessed 27 Oct. 2019).

Schultz, D. \& Kitchen, P., (1997). Integrated marketing communications in US advertising agencies: an exploratory study. Journal of Advertising Research, 37(5), p.7-17.

Schultz, D.E., (2004). IMC Next Generation. New York: McGraw-Hill.

Schultz, D.E., (2011). IMC Measurement: The Challenges of an Interactive Marketplace. International Journal of Integrated Marketing Communications, 3(1), p. 7.

VinaResearch. (2018, April 27). Research Report on Vietnamese social network habits in 2018 (Báo cáo nghiên cúu thói quen sủ dụng mạng xã hội của ngườ Việt Nam 2018). Retrieved from vinaresearch.net: https://vinaresearch.net/public/news/2201 - bao-cao-nghien-cuu-thoi-quen-su-dung-mang-xa-hoi-cua-nguoi-vietnam- 2018.vnrs (Accessed 24 Oct. 2019).

Vo Hung (2018, December 22). Digital marketing trends in Vietnam 2019. Retrieved from Advertising Vietnam: https://advertisingvietnam.com/2018/12/xu- huong-tiep-thi-truc-tuyen-tai-viet-nam-2019/ (Accessed 26 Oct. 2019) 